\title{
A STUDY OF TWO YEARS' WORK IN NORTHERN IRELAND
}

\section{GENERAL PRACTICE}

\author{
BY \\ J. C. C. CRAWFORD \\ Belfast
}

\section{INTRODUCTION}

When it is appreciated that it is to the general practitioner that almost all sick people turn for medical attention or advice, and that it is through his hands that they first pass, it is perhaps surprising that until the last few years so few contributions to the study of morbidity have been made by family doctors. The pioneer work of McGregor (1949, $1950,1953)$ and Fry (1952) among others broke the ground in this field, but the feeling grew that a wider picture, covering different types of general practice, would contribute more to the understanding of the subject than would single practice studies. Accordingly the General Register Office has published a preliminary analysis of records from eight general practices (Logan, 1953) and the College of General Practitioners is planning an investigation on similar lines. Nevertheless, there is still a place for individual studies in this field. There is, for example, greater uniformity in applying medical terms to the different morbid conditions encountered, when diagnosis is the work of one practitioner. Logan (1953) has instanced the common disparities between his practitioners in this respect. The following account of work in my practice during two separate periods each of one year (from November 1951 to October 1952, and November 1952 to October 1953) may therefore be of value in contrasting two years of study and for comparison with other single practice reports such as those mentioned above, and that reported by Backett, Shaw, and Evans (1953) and Backett, Heady, and Evans (1954).

\section{Description of Practice}

The practice is a suburban one in the south of Belfast, an industrial county borough with a population of 443,671 at the 1951 census. The majority of the patients can be described as "middle class"; no particular occupational or industrial group predominates. The area of the practice is limited to about 4 square miles and involves an annual car mileage of about 8,000 miles. The practice is run single-handed with the non-professional assistance of a part-time secretary-receptionist and adequate domestic help. There is a loose arrangement as regards "off duty" work with a neighbouring practitioner, who at one time was an assistant in my practice, and who has the same outlook on general practice. At holiday times he has preserved the continuity of the records used in the present survey. Each of our houses has a telephone extension to the other so that frequent contact and exchange of thought is encouraged.

The practice is fortified by ample hospital and laboratory services and both out-patient and in-patient facilities are frequently used. As in most urban areas, no hospital beds are available for the general practitioner, and although he is welcome to visit his patients he has no share in their treatment while they are in hospital. Pay clinics and private nursing homes are available for patients who wish to pay for their treatment; the nursing homes are becoming steadily fewer, but it appears that the clinics, attached as they are to the hospitals and with better diagnostic facilities, are as busy as ever they were.

The working day in the practice starts at 9 a.m.; the morning is devoted to visits to patients; between 2 and 4 p.m. patients are seen at the surgery; private patients can be seen by appointment between 2 and 3 p.m. Between 4 and 6 p.m. further visits are made to patients' homes. The evening surgery usually lasts till about $8 \mathrm{p} . \mathrm{m}$. Thereafter the day is free, apart from emergency calls and night visits, fortunately rarer, in this practice, than the public imagines. Life assurance examinations and other special consultations are fitted into the day by arrangement.

The pressure of work varies considerably. In the summer and early autumn there is enough free time 
to enable the doctor to catch up on the medical reading which has largely to be postponed at other seasons.

\section{Composition of Practice}

The potential patients of the practice can be classified into three groups:

(1) About 1,400 registered under the National Health Service.

(2) About 200 private patients, requiring often extra and perhaps disproportionate attention, and some at least coming privately at one time, and at another attending their own "panel" doctor.

(3) A large body of students at a Training College, of a narrow age group, who are given service only during college terms.

Groups 2 and 3 have been omitted from the present survey in view of the special circumstances involved.

Table I shows the variations in Group 1 during each of the 2 years under review. In this and subsequent tables "Year 1" refers to 1951-52 and "Year 2" to 1952-53, each year beginning on November 1 . Of the 1,488 patients on the register at the beginning of the first year, 1,384 remained on the register throughout that year. For the second year the comparable figures were 1,450 and 1,341. It was considered more satisfactory to analyse the experience of only those patients who were on the list for the complete 12 months of each period of study. Their age and sex distributions are shown in the last two columns of Table I, and it will be seen that in each year they do not differ materially from those of the average populations exposed to risk. Moreover this procedure permits compilation of precise frequency distributions of sickness events which are of considerable value in these studies.

For some purposes, e.g. consideration of births and deaths, it has been necessary to talk in terms of the complete register, but where this is done it is specifically stated, and in the absence of such statements all the comments which follow refer to the experience of the 1,384 patients who were with the practice throughout the whole year of 1951-52 and the corresponding group of 1,341 for $1952-53$.

\section{RECORDING SYSTEM}

Medical attention given to patients was classified according to the International Statistical Classification of Diseases, Injuries, and Causes of Death (World Health Organization, 1948). Each attendance of a patient at the surgery and each visit to the home of a patient was recorded. In the Tables and discussion which follows these are referred to as "surgery attendances" and "home visits" respectively. Continuous attention, that is, a series of connected surgery attendances and/or home visits is described as a "spell of medical attention". In most instances a spell can be regarded as a complete illness but some caution is needed in so interpreting it; for example inoculations and most obstetric work cannot be so described.
A record card was available for each patient on the register, showing name, age, sex, and address. Each card was ruled horizontally to give a line for each month of the year and had a number of columns which were allotted to diagnostic entities as they arose. In the cells of the grid so formed entries were made to show the number of surgery attendances and home visits each month for each classified diagnosis. The information was entered on the cards by extracting the relevant information from the medical records maintained in the routine administration of the practice.

Separate records were kept of referrals of patients to hospital externs and consultants and of admissions to hospitals and pay clinics, distinguishing the various specialist services involved.

Thus a number of activities associated with general practice are omitted from this study. No mention has been made of special examinations for life assurance, emigration, or special employment, requests for "a check up", or the demands of temporary Health Service patients. Similarly no record has been made of certifications and of requests for prescriptions to be repeated, nor was it possible to assess telephone conversations in which medical advice was given. If no other medical attention was involved these small services have been ignored.

\section{Available Data}

Thus for each patient on the register the following information is available for analysis for each year:

(1) Age and sex.

(2) Number of surgery attendances made each month classified by diagnosis.

(3) Number of home visits made each month classified by diagnosis.

(4) Number of separate spells of medical attention classified by diagnosis.

(5) Number of referrals to a hospital extern, classified by type of clinic.

(6) Number of referrals to a consultant, classified by specialist service involved and whether seen in own home or specialist's consulting room.

(7) Number of admissions to hospitals, classified by hospital department.

(8) Number of admissions to a pay clinic, classified by type of admission.

The possible combinations of these eight items for any group of patients into various types of index or rate are of course numerous. I have, therefore, selected those combinations which appear to be of particular interest and presented statistics for the age and sex groups shown in the Tables. In the present analysis no attempt has been made to consider the month to month, or seasonal variations (Items 2-4 above are available in monthly periods); it has been preferred to postpone such analysis and to deal with it separately. 


\section{Population at Risk}

The age and sex distribution of the patients studied is shown in the last two columns of Table $I$. The age and sex distribution of the 1,384 patients studied in 1951-52 is very similar to that of the 1,341 in 1952-53. In each period there were more males than females under the age of 15 , but at later ages women out-numbered men, as they did for all ages combined.

TABLE I

COMPOSITION OF REGISTER FOR THE YEARS 1951-52 AND 1952-53

\begin{tabular}{|c|c|c|c|c|c|}
\hline \multicolumn{2}{|c|}{ Age Group (yrs) } & \multicolumn{2}{|c|}{$\begin{array}{c}\text { Average Number of } \\
\text { Patients during } \\
\text { Year* }\end{array}$} & \multicolumn{2}{|c|}{$\begin{array}{l}\text { Number of Patients } \\
\text { on Register for } \\
\text { Whole Year* }\end{array}$} \\
\hline & & Year 1 & Year 2 & Year 1 & Year 2 \\
\hline \multirow[t]{2}{*}{ Male } & $\begin{array}{l}0- \\
5- \\
15- \\
40- \\
60+\end{array}$ & $\begin{array}{r}48 \cdot 5 \\
97.5 \\
182.5 \\
168.0 \\
117.0\end{array}$ & $\begin{array}{r}44.0 \\
102.5 \\
167.5 \\
163.5 \\
116.0\end{array}$ & $\begin{array}{r}43 \\
93 \\
171 \\
164 \\
112\end{array}$ & $\begin{array}{r}40 \\
98 \\
157 \\
157 \\
111\end{array}$ \\
\hline & Total & $613 \cdot 5$ & $593 \cdot 5$ & 583 & 563 \\
\hline \multirow[t]{2}{*}{ Female } & $\begin{array}{l}0- \\
5- \\
15- \\
40- \\
60+\end{array}$ & $\begin{array}{r}41 \cdot 5 \\
91 \cdot 5 \\
272.0 \\
256.0 \\
194.5\end{array}$ & $\begin{array}{r}32.5 \\
88.0 \\
252.5 \\
262.0 \\
191.5\end{array}$ & $\begin{array}{r}35 \\
87 \\
247 \\
245 \\
187\end{array}$ & $\begin{array}{r}29 \\
86 \\
228 \\
251 \\
184\end{array}$ \\
\hline & Total & $855 \cdot 5$ & $826 \cdot 5$ & 801 & 778 \\
\hline
\end{tabular}

"In this and subsequent Tables "Year 1" refers to the year 1951-52 "Year 2" refers to the year 1952-53.

Of the 1951-2 practice population, 5.6 per cent. were of pre-school age, and 13.0 per cent. of school age; in the age groups 15-39, 40-59, and 60 and over, the percentages were $30 \cdot 2,29 \cdot 6$, and $21 \cdot 6$. The comparable percentages for the second year were $5 \cdot 1,13 \cdot 7,28 \cdot 7,30 \cdot 4$, and $22 \cdot 0$.

If for the moment private patients in this second year are considered, taking only those that can be described as settled (as against those coming occasionally as private patients), there are only nine males under 60 years old as against 34 aged 60 and over; among females there are 22 under 60 years old and eighty aged 60 and over. This underlines how largely private practice has now become the care of the elderly. Indeed, if the private patients are added to those on the register, the proportion aged 60 and over becomes 27.5 per cent., a truly remarkable figure for any practice. This may be compared with 13.8 per cent. for the same age group in the Northern Ireland population as a whole.

\section{WORK DONE}

The accompanying Tables give an impression of the work done in practice during the 2 years and provide figures for comparison between them. In general the 2 years presented remarkably similar pictures. Both years were fairly average ones, without major epidemics. (It may be pointed out, however, that attendance on patients excluded from the investigation as described earlier, as well as insurance and other work, probably occupied nearly as much time as that devoted to the population under consideration.)

Table II shows the average number of surgery attendances, and/or home visits per patient on the register in each of the 2 years under study for each age and sex group. Altogether there were 2,404 surgery attendances and 1,919 home visits in the first year, and 2,298 and 2,074 respectively in the second year. The average number of home visits and surgery attendances over the whole period was 3.19 per patient on the register and varied between about two and five per patient in the tabulated age and sex groups. In three age groups females demanded more attention on the average than males in the first year, but this was true of only one age group in the second year, thus these data give no support to a consistent sex difference. It should be noted, however, that male averages were greater in both years among school children and amongst persons aged 60 and over. This Table demonstrates the well recognized fact that the heaviest work in general practice is in connection with the very young and the old, the 15-39 years age group in both years and both sexes demanding least of all.

\section{TABLE II}

AVERAGE NUMBER OF SURGERY ATTENDANCES AND/OR HOME VISITS PER PATIENT ON REGISTER DURING THE YEARS 1951-52 AND 1952-53

\begin{tabular}{|c|c|c|c|c|c|}
\hline \multirow{2}{*}{\multicolumn{2}{|c|}{ Age Group (yrs) }} & \multicolumn{2}{|c|}{$\begin{array}{c}\text { Average Number of } \\
\text { Surgery Attendances } \\
\text { and/or Home Visits } \\
\text { per Patient on } \\
\text { Register }\end{array}$} & \multicolumn{2}{|c|}{$\begin{array}{l}\text { Surgery Attendances } \\
\text { as Percentage of } \\
\text { Total }\end{array}$} \\
\hline & & Year 1 & Year 2 & Year 1 & Year 2 \\
\hline \multirow[t]{2}{*}{ Male } & $\begin{array}{l}0- \\
5- \\
15- \\
40- \\
60+\end{array}$ & $\begin{array}{l}4 \cdot 12 \\
3 \cdot 40 \\
1 \cdot 95 \\
2 \cdot 26 \\
4 \cdot 75\end{array}$ & $\begin{array}{l}4 \cdot 28 \\
4 \cdot 35 \\
2 \cdot 34 \\
2 \cdot 39 \\
4 \cdot 65\end{array}$ & $\begin{array}{l}49 \cdot 7 \\
42 \cdot 7 \\
73 \cdot 6 \\
64 \cdot 3 \\
40 \cdot 4\end{array}$ & $\begin{array}{l}39 \cdot 2 \\
34 \cdot 5 \\
73 \cdot 3 \\
61 \cdot 4 \\
42 \cdot 4\end{array}$ \\
\hline & Total & $2 \cdot 96$ & $3 \cdot 30$ & $53 \cdot 3$ & $50 \cdot 3$ \\
\hline \multirow[t]{2}{*}{ Female } & $\begin{array}{l}0- \\
5- \\
15- \\
40- \\
60+\end{array}$ & $\begin{array}{l}4 \cdot 57 \\
3 \cdot 22 \\
2 \cdot 52 \\
2 \cdot 98 \\
4 \cdot 29\end{array}$ & $\begin{array}{l}3 \cdot 48 \\
3 \cdot 67 \\
2 \cdot 29 \\
2 \cdot 92 \\
4 \cdot 59\end{array}$ & $\begin{array}{l}31 \cdot 3 \\
45 \cdot 7 \\
71 \cdot 7 \\
62 \cdot 6 \\
50 \cdot 1\end{array}$ & $\begin{array}{l}38 \cdot 6 \\
37 \cdot 3 \\
78 \cdot 4 \\
67 \cdot 5 \\
36 \cdot 1\end{array}$ \\
\hline & Total & $3 \cdot 24$ & $3 \cdot 23$ & $57 \cdot 1$ & $54 \cdot 3$ \\
\hline
\end{tabular}

A study of the ratio of surgery attendances to home visits shows in both years and in both sexes a relatively high proportion of home visits up to the age of 15 . From that age up to 60 years the proportion of visits is relatively low, and it then increases 
again after that age. Thus not only was the total volume of attention greater at the extreme ages, but also the type of attention was different, in that it included more visits to the patients' homes.

Table III shows the cumulative percentage distribution of patients by number of surgery attendances and home visits combined during each of the 2 years of study. Thus in the first year only $9 \cdot 3$ per cent. of all boys under 5 were not seen at all, 30.2 per cent. were seen not more than once, $44 \cdot 2$ per cent. not more than twice, and so on. Incidentally, in the second year only one boy under 5 did not require medical attention. On the whole, however, the figures for the 2 years are very similar. It will be noted that 35.7 per cent. of the males during the first year and 35.0 per cent. during the second did not ask for my services. Among the females the figures are not quite so similar, being $36 \cdot 1$ and $32 \cdot 4$ per cent. respectively. In each age group and in both sexes the percentage who were not seen at all increased up to the age of 60 . After that age, as might be expected, the percentage again became smaller, though not at all strikingly in the second year among females.
Table IV shows the number of spells of medical attention, as opposed to the amount of work done expressed as surgery attendances and/or home visits. Thus in the first year the 43 males in the $0-4$ yrs age group had 115 spells of medical attention

TABLE IV

SPELLS OF MEDICAL ATTENTION DURING THE YEARS 1951-52 and 1952-53

\begin{tabular}{|c|c|c|c|c|c|}
\hline \multirow{3}{*}{\multicolumn{2}{|c|}{ Age Group (yrs) }} & \multicolumn{4}{|c|}{ Spells of Medical Attention } \\
\hline & & \multicolumn{2}{|c|}{ Year 1} & \multicolumn{2}{|c|}{ Year 2} \\
\hline & & Total No. & $\begin{array}{c}\text { No. per } \\
\text { Patient on } \\
\text { Register }\end{array}$ & Total No. & $\begin{array}{l}\text { No. per } \\
\text { Patient on } \\
\text { Register }\end{array}$ \\
\hline \multirow[t]{2}{*}{ Male } & $\begin{array}{l}0- \\
5- \\
15- \\
40- \\
60+\end{array}$ & $\begin{array}{l}115 \\
200 \\
181 \\
173 \\
170\end{array}$ & $\begin{array}{l}2 \cdot 67 \\
2 \cdot 15 \\
1 \cdot 06 \\
1 \cdot 05 \\
1 \cdot 52\end{array}$ & $\begin{array}{l}117 \\
241 \\
190 \\
155 \\
153\end{array}$ & $\begin{array}{l}2.93 \\
2.46 \\
1 \cdot 21 \\
0.99 \\
1 \cdot 38\end{array}$ \\
\hline & Total & 839 & $1 \cdot 44$ & 856 & $1 \cdot 52$ \\
\hline \multirow[t]{2}{*}{ Female } & $\begin{array}{l}0- \\
5- \\
15- \\
40- \\
60+\end{array}$ & $\begin{array}{r}89 \\
160 \\
338 \\
348 \\
293\end{array}$ & $\begin{array}{l}2 \cdot 54 \\
1 \cdot 84 \\
1 \cdot 37 \\
1 \cdot 42 \\
1 \cdot 57\end{array}$ & $\begin{array}{r}67 \\
180 \\
332 \\
353 \\
264\end{array}$ & $\begin{array}{l}2.31 \\
2.09 \\
1.46 \\
1.41 \\
1.43\end{array}$ \\
\hline & Total & 1,228 & $1 \cdot 53$ & 1,196 & $1 \cdot 54$ \\
\hline
\end{tabular}

TABLE III

CUMULATIVE PERCENTAGE DISTRIBUTION OF PATIENTS BY NUMBER OF SURGERY ATTENDANCES AND/OR HOME VISITS MADE DURING THE YEARS 1951-52 AND 1952-53

\begin{tabular}{|c|c|c|c|c|c|c|c|c|c|}
\hline \multirow{2}{*}{\multicolumn{2}{|c|}{ Age Group (yrs) }} & \multirow{3}{*}{$\begin{array}{c}\text { Year } \\
\mathbf{1} \\
2\end{array}$} & \multicolumn{5}{|c|}{ Number of Surgery Attendances and/or Home Visits } & \multicolumn{2}{|c|}{ Total } \\
\hline & & & 0 & 1 or less & 2 or less & 3 or less & 4 or less & $\%$ & $\begin{array}{c}\text { Nos. on } \\
\text { 'which Per- }\end{array}$ \\
\hline \multirow{6}{*}{ Males } & 0 & & $\begin{array}{l}9 \cdot 3 \\
2 \cdot 5\end{array}$ & $\begin{array}{r}30 \cdot 2 \\
7 \cdot 5\end{array}$ & $\begin{array}{l}44 \cdot 2 \\
15 \cdot 0\end{array}$ & $\begin{array}{l}55 \cdot 8 \\
35.0\end{array}$ & $\begin{array}{l}67 \cdot 4 \\
67 \cdot 5\end{array}$ & $\begin{array}{l}100 \\
100\end{array}$ & $\begin{array}{l}43 \\
40\end{array}$ \\
\hline & $5-$ & $\begin{array}{l}1 \\
2\end{array}$ & $\begin{array}{l}18 \cdot 3 \\
21 \cdot 4\end{array}$ & $\begin{array}{l}35 \cdot 5 \\
33 \cdot 7\end{array}$ & $\begin{array}{l}49 \cdot 5 \\
40 \cdot 8\end{array}$ & $\begin{array}{l}63.4 \\
50.0\end{array}$ & $\begin{array}{l}73 \cdot 1 \\
58 \cdot 2\end{array}$ & $\begin{array}{l}100 \\
100\end{array}$ & $\begin{array}{l}93 \\
98\end{array}$ \\
\hline & $15-$ & $\begin{array}{l}1 \\
2\end{array}$ & $\begin{array}{l}43.9 \\
40.8\end{array}$ & $\begin{array}{l}63 \cdot 7 \\
57 \cdot 3\end{array}$ & $\begin{array}{l}76 \cdot 0 \\
70 \cdot 1\end{array}$ & $\begin{array}{l}83 \cdot 0 \\
78 \cdot 3\end{array}$ & $\begin{array}{l}86 \cdot 0 \\
83.4\end{array}$ & $\begin{array}{l}100 \\
100\end{array}$ & $\begin{array}{l}171 \\
157\end{array}$ \\
\hline & 40 & 1 & $\begin{array}{l}48 \cdot 8 \\
43 \cdot 9\end{array}$ & $\begin{array}{l}65 \cdot 2 \\
61 \cdot 1\end{array}$ & $\begin{array}{l}75 \cdot 0 \\
73 \cdot 9\end{array}$ & $\begin{array}{l}81 \cdot 1 \\
82 \cdot 2\end{array}$ & $\begin{array}{l}84 \cdot 8 \\
86 \cdot 0\end{array}$ & $\begin{array}{l}100 \\
100\end{array}$ & $\begin{array}{l}164 \\
157\end{array}$ \\
\hline & $60+$ & $\begin{array}{l}1 \\
2\end{array}$ & $\begin{array}{l}28 \cdot 6 \\
37 \cdot 8\end{array}$ & $\begin{array}{l}45 \cdot 5 \\
50 \cdot 5\end{array}$ & $\begin{array}{l}54 \cdot 5 \\
62 \cdot 2\end{array}$ & $\begin{array}{l}67 \cdot 9 \\
68 \cdot 5\end{array}$ & $\begin{array}{l}73 \cdot 2 \\
71 \cdot 2\end{array}$ & $\begin{array}{l}100 \\
100\end{array}$ & $\begin{array}{l}112 \\
111\end{array}$ \\
\hline & Total & $\begin{array}{l}1 \\
2\end{array}$ & $\begin{array}{l}35 \cdot 7 \\
35.0\end{array}$ & $\begin{array}{l}53 \cdot 7 \\
49 \cdot 4\end{array}$ & $\begin{array}{l}65 \cdot 0 \\
60.6\end{array}$ & $\begin{array}{l}74 \cdot 4 \\
69 \cdot 4\end{array}$ & $\begin{array}{l}79 \cdot 8 \\
76 \cdot 2\end{array}$ & $\begin{array}{l}100 \\
100\end{array}$ & $\begin{array}{l}583 \\
563\end{array}$ \\
\hline \multirow{6}{*}{ Females } & 0 & $\begin{array}{l}1 \\
2\end{array}$ & $\begin{array}{l}11.4 \\
13.8\end{array}$ & $\begin{array}{l}28 \cdot 6 \\
20 \cdot 7\end{array}$ & $\begin{array}{l}48 \cdot 6 \\
41 \cdot 4\end{array}$ & $\begin{array}{l}51 \cdot 4 \\
55 \cdot 2\end{array}$ & $\begin{array}{l}54 \cdot 3 \\
69 \cdot 0\end{array}$ & $\begin{array}{l}100 \\
100\end{array}$ & $\begin{array}{l}35 \\
29\end{array}$ \\
\hline & 5- & 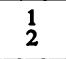 & $\begin{array}{l}25 \cdot 3 \\
24 \cdot 4\end{array}$ & $\begin{array}{l}34 \cdot 5 \\
37 \cdot 2\end{array}$ & $\begin{array}{l}52.9 \\
51.2\end{array}$ & $\begin{array}{l}63 \cdot 2 \\
65 \cdot 1\end{array}$ & $\begin{array}{l}74 \cdot 7 \\
68 \cdot 6\end{array}$ & $\begin{array}{l}100 \\
100\end{array}$ & $\begin{array}{l}87 \\
86\end{array}$ \\
\hline & 15- & $\begin{array}{l}1 \\
2\end{array}$ & $\begin{array}{l}38.5 \\
32.9\end{array}$ & $\begin{array}{l}55 \cdot 1 \\
52 \cdot 6\end{array}$ & $\begin{array}{l}70 \cdot 0 \\
63.6\end{array}$ & $\begin{array}{l}78 \cdot 5 \\
72 \cdot 8\end{array}$ & $\begin{array}{l}83 \cdot 4 \\
82.9\end{array}$ & $\begin{array}{l}100 \\
100\end{array}$ & $\begin{array}{l}247 \\
228\end{array}$ \\
\hline & $40-$ & $\begin{array}{l}1 \\
2\end{array}$ & $\begin{array}{l}40.4 \\
35.1\end{array}$ & $\begin{array}{l}57 \cdot 1 \\
55 \cdot 0\end{array}$ & $\begin{array}{l}68 \cdot 2 \\
64 \cdot 9\end{array}$ & $\begin{array}{l}75 \cdot 1 \\
71 \cdot 7\end{array}$ & $\begin{array}{l}80 \cdot 4 \\
78.9\end{array}$ & $\begin{array}{l}100 \\
100\end{array}$ & $\begin{array}{l}245 \\
251\end{array}$ \\
\hline & $60+$ & $\begin{array}{l}1 \\
2\end{array}$ & $\begin{array}{l}36.9 \\
34.8\end{array}$ & $\begin{array}{l}49.7 \\
50.0\end{array}$ & $\begin{array}{l}57 \cdot 8 \\
56 \cdot 5\end{array}$ & $\begin{array}{l}66.8 \\
63.0\end{array}$ & $\begin{array}{l}74 \cdot 9 \\
70 \cdot 1\end{array}$ & $\begin{array}{l}100 \\
100\end{array}$ & $\begin{array}{l}187 \\
184\end{array}$ \\
\hline & Total & $\begin{array}{l}1 \\
2\end{array}$ & $\begin{array}{l}36 \cdot 1 \\
32 \cdot 4\end{array}$ & $\begin{array}{l}51 \cdot 1 \\
49 \cdot 9\end{array}$ & $\begin{array}{l}63 \cdot 8 \\
60 \cdot 2\end{array}$ & $\begin{array}{l}71 \cdot 9 \\
68.6\end{array}$ & $\begin{array}{l}78 \cdot 3 \\
76 \cdot 5\end{array}$ & $\begin{array}{l}100 \\
100\end{array}$ & $\begin{array}{l}801 \\
778\end{array}$ \\
\hline
\end{tabular}


or 2.67 spells per patient. It will be noticed that the average number of spells per patient was relatively high up to 15 years, after which it steadily decreased with each age group up to 60 years. There was then a definite rise, less marked in the females. Comparison of the 2 years shows an increase in the second year in the number of spells per patient under 40 years of age, and a decrease in later age groups, the total average number of spells per patient being very similar in the 2 years.

Table $\mathrm{V}$ contrasts the surgery attendances and home visits per spell of medical attention, and allows a number of comparisons to be made. The totals for combined surgery attendances and visits in the 2 years, and for each sex, are remarkably similar, and though there is variation between the years in the different age groups no consistent pattern is apparent. In total the average number of visits and/or attendances per spell was just over two and varied from about 1.5 among children to about three or more in the oldest age group. Generally there was a fairly steady rise in the number of combined attendances and home visits per spell of medical attention as age advanced. In both years home visits predominated up to age 15 , but from then until age 60 surgery attendances exceeded home visits in each spell of medical attention. After age 60 the tendency of old people to need relatively more home attention is again shown. Naturally old people are often unable to come to the surgery even for conditions which are not serious in themselves, and many old people receive real encouragement

\section{TABLE V}

AVERAGE NUMBER OF SURGERY ATTENDANCES AND/OR HOME VISITS PER SPELL OF MEDICAL ATTENTION DURING THE YEARS 1951-52 AND 1952-53

\begin{tabular}{|c|c|c|c|c|c|c|c|}
\hline \multirow{3}{*}{\multicolumn{2}{|c|}{ Age Group (yrs) }} & \multicolumn{6}{|c|}{$\begin{array}{l}\text { Average Number of Surgery Attendances } \\
\text { and/or Home Visits per Spell of Medical } \\
\text { Attention }\end{array}$} \\
\hline & & \multicolumn{2}{|c|}{$\begin{array}{c}\text { Surgery } \\
\text { Attendances }\end{array}$} & \multicolumn{2}{|c|}{$\begin{array}{l}\text { Home } \\
\text { Visits }\end{array}$} & \multicolumn{2}{|c|}{ Total } \\
\hline & & $\begin{array}{c}\text { Year } \\
1\end{array}$ & $\underset{2}{\text { Year }}$ & $\begin{array}{c}\text { Year } \\
1\end{array}$ & $\underset{2}{\text { Year }}$ & $\underset{1}{\text { Year }}$ & Year $_{2}$ \\
\hline \multirow[t]{2}{*}{ Male } & $\begin{array}{c}0- \\
5- \\
15- \\
40- \\
60+\end{array}$ & $\begin{array}{l}0.77 \\
0.68 \\
1.35 \\
1.38 \\
1.26\end{array}$ & $\begin{array}{l}0.57 \\
0.61 \\
1.42 \\
1.49 \\
1.43\end{array}$ & $\begin{array}{l}0.77 \\
0.91 \\
0.49 \\
0.76 \\
1.86\end{array}$ & $\begin{array}{l}0.89 \\
1.16 \\
0.52 \\
0.94 \\
1.94\end{array}$ & $\begin{array}{l}1.54 \\
1.58 \\
1.84 \\
2.14 \\
3.13\end{array}$ & $\begin{array}{l}1.46 \\
1.77 \\
1.93 \\
2.43 \\
3.37\end{array}$ \\
\hline & Total & $1 \cdot 10$ & 1.09 & 0.97 & $1 \cdot 08$ & $2 \cdot 06$ & $2 \cdot 17$ \\
\hline \multirow[t]{2}{*}{ Female } & $\begin{array}{c}0- \\
5- \\
15- \\
40- \\
60+\end{array}$ & $\begin{array}{l}0 \cdot 56 \\
0 \cdot 80 \\
1 \cdot 32 \\
1 \cdot 31 \\
1 \cdot 37\end{array}$ & $\begin{array}{l}0.58 \\
0.66 \\
1.23 \\
1.40 \\
1.16\end{array}$ & $\begin{array}{l}1.24 \\
0.95 \\
0.52 \\
0.78 \\
1.37\end{array}$ & $\begin{array}{l}0.93 \\
1 \cdot 10 \\
0.34 \\
0.67 \\
2.05\end{array}$ & $\begin{array}{l}1 \cdot 80 \\
1 \cdot 75 \\
1 \cdot 84 \\
2 \cdot 10 \\
2 \cdot 74\end{array}$ & $\begin{array}{l}1 \cdot 51 \\
1.76 \\
1.57 \\
2.07 \\
3.20\end{array}$ \\
\hline & Total & $1 \cdot 21$ & $1 \cdot 14$ & 0.91 & 0.96 & $2 \cdot 11$ & $2 \cdot 10$ \\
\hline
\end{tabular}

from periodic visits from the doctor, quite apart from the treatment of any specific illness, and the frequent small discomforts of old age can then be discussed.

\section{MORBIDITY}

In Table VI (overleaf) the spells of medical attention have been classified by age and sex of patient and diagnosis. The indices shown are the average number of spells of medical attention per patient on the register in each year, and it will be appreciated that in some instances these averages are based on rather small numbers (see the totals in Table IV). Consequently one can do no more here than comment on the consistent trends which emerge from a study of Table VI.

The composition of the nineteen diagnostic groups used is apparent from the International List numbers, but it is necessary to describe the contents of some groups in so far as this practice is concerned. Tuberculosis forms a very small part of the infectious diseases group; no new cases were detected in either year; in the first year four old patients were attended, but none was seen in the second year. Among mental conditions psycho-neurosis predominated. Cardiovascular disease included such disorders as chilblains, varicose veins, and haemorrhoids. Among skin diseases were classed subcutaneous infections, such as cellulitis and whitlows, but allergic skin disorders were included among the allergies. Ill-defined conditions comprised the tired and the run-down, and questions of old age and infant management.

For all ages combined for both years and both sexes, the highest average number of spells was attributed to diseases of the respiratory tract including influenza. This diagnosis accounted for about 25 per cent. of all spells of sickness experienced by males and for about 20 per cent. of those experienced by females. The average number of spells per patient in the first year was 0.32 for males and 0.26 for females, and in the second year 0.43 and 0.34 per cent. respectively; no other diagnostic group exceeded a level of 0.16 spells per patient.

In the pre-school age group, $0-4$ years, respiratory diseases again gave the maximum average number of spells per patient in each year and for each sex. The averages were 0.88 for males and 0.66 for females in the first year and 0.80 and 0.83 in the second year. This represented about 25 to 35 per cent. of all spells of sickness experienced in this age group. Infectious diseases, allergic disorders, and diseases of the alimentary tract also ranked fairly high in this age group. 
TABLE VI

AVERAGE NUMBER OF SPELLS OF MEDICAL ATTENTION PER PATIENT ON REGISTER, BY DIAGNOSIS

DURING THE YEARS 1951-52 AND 1952-53

\begin{tabular}{|c|c|c|c|c|c|c|c|c|c|c|c|c|c|c|}
\hline \multirow{3}{*}{$\begin{array}{c}\text { Interna- } \\
\text { tional } \\
\text { Classifi- } \\
\text { cation } \\
\text { Numbers }\end{array}$} & \multirow{3}{*}{ Diagnosis } & \multirow{3}{*}{ Year } & \multicolumn{6}{|c|}{ Male } & \multicolumn{6}{|c|}{ Female } \\
\hline & & & \multicolumn{6}{|c|}{ Age Group (yrs) } & \multicolumn{6}{|c|}{ Age Group (yrs) } \\
\hline & & & 0 & 5 & 15 & 40 & $60+$ & Total & 0 & $5-$ & 15 & 40 & $60+$ & Total \\
\hline $001-138$ & $\begin{array}{l}\text { Infectious di } \\
\text { ing tubercul }\end{array}$ & $\begin{array}{l}1 \\
2\end{array}$ & $\begin{array}{l}0.21 \\
0.43\end{array}$ & $\begin{array}{l}0.38 \\
0.42\end{array}$ & $\begin{array}{l}.05 \\
.03\end{array}$ & $\begin{array}{l}0.03 \\
0.01\end{array}$ & $\begin{array}{l}0.01 \\
0.01\end{array}$ & $\begin{array}{l}0.10 \\
0.11\end{array}$ & $\begin{array}{l}0.43 \\
0.31\end{array}$ & $\begin{array}{l}0 \cdot 31 \\
0 \cdot 29\end{array}$ & $\begin{array}{l}0.06 \\
0.04\end{array}$ & $\begin{array}{l}0.02 \\
0.02\end{array}$ & $\overline{0.02}$ & $\begin{array}{l}0.07 \\
0.07\end{array}$ \\
\hline $140-239$ & Tum & $\begin{array}{l}1 \\
2\end{array}$ & $\begin{array}{c}0.02 \\
-\end{array}$ & $=$ & $\begin{array}{c}0.01 \\
-\end{array}$ & $\begin{array}{l}0.01 \\
0.01\end{array}$ & $\begin{array}{l}0.01 \\
0.01\end{array}$ & $\begin{array}{l}0.01 \\
0.01\end{array}$ & 二 & $\overline{0.01}$ & $\begin{array}{l}0.004 \\
0.02\end{array}$ & $\overline{0.02}$ & 0.01 & $\begin{array}{l}0.002 \\
0.01\end{array}$ \\
\hline $240-245$ & Allergic disorders & $\frac{1}{2}$ & $\begin{array}{l}0 \cdot 30 \\
0 \cdot 23\end{array}$ & $\begin{array}{l}0.15 \\
0.07\end{array}$ & $\begin{array}{l}0.05 \\
0.04\end{array}$ & $\begin{array}{l}0.02 \\
0.03\end{array}$ & $\begin{array}{l}0.03 \\
0.03\end{array}$ & $\begin{array}{l}0.07 \\
0.05\end{array}$ & $\begin{array}{l}0 \cdot 20 \\
0 \cdot 17\end{array}$ & $\begin{array}{l}0.09 \\
0.12\end{array}$ & $\begin{array}{l}0.05 \\
0.04\end{array}$ & $\begin{array}{l}0.05 \\
0.04\end{array}$ & $\begin{array}{l}0.04 \\
0.02\end{array}$ & $\begin{array}{l}0.06 \\
0.05\end{array}$ \\
\hline $250-289$ & rs, with & $\begin{array}{l}1 \\
2\end{array}$ & $0 . \overline{03}$ & $\begin{array}{c}0.01 \\
-\end{array}$ & $\begin{array}{l}0.02 \\
0.01 \\
\end{array}$ & $\begin{array}{l}0.02 \\
0.03\end{array}$ & $\begin{array}{l}0.03 \\
0.01 \\
\end{array}$ & $\begin{array}{l}0.02 \\
0.01 \\
\end{array}$ & $\overline{0.03}$ & $0 \overline{0}$ & $\begin{array}{l}0.02 \\
0.03\end{array}$ & $\begin{array}{l}0.05 \\
0.03\end{array}$ & $\begin{array}{l}0.03 \\
0.02 \\
\end{array}$ & $\begin{array}{l}0.03 \\
0.03 \\
\end{array}$ \\
\hline $290-299$ & Anaemias & $\frac{1}{2}$ & $\begin{array}{c}0.02 \\
-\end{array}$ & $\begin{array}{c}0.02 \\
-\end{array}$ & $\begin{array}{c}0.01 \\
-\end{array}$ & - & $\begin{array}{c}0.01 \\
-\end{array}$ & $\begin{array}{c}0.01 \\
-\end{array}$ & $\begin{array}{c}0.06 \\
-\end{array}$ & $\begin{array}{c}0.01 \\
-\end{array}$ & $\begin{array}{c}0.01 \\
-\end{array}$ & $\begin{array}{l}0.01 \\
0.004\end{array}$ & $\begin{array}{l}0.03 \\
0.02\end{array}$ & $\begin{array}{l}0.02 \\
0.01\end{array}$ \\
\hline $300-326$ & Mental conditions & $\begin{array}{l}1 \\
2\end{array}$ & $\begin{array}{l}0.07 \\
0.05\end{array}$ & $\begin{array}{l}0.09 \\
0.09\end{array}$ & $\begin{array}{l}0.05 \\
0.04\end{array}$ & $\begin{array}{l}0.09 \\
0.09\end{array}$ & $\begin{array}{l}0.04 \\
0.05\end{array}$ & $\begin{array}{l}0.07 \\
0.07\end{array}$ & $0 \overline{03}$ & $\begin{array}{l}0.03 \\
0.05\end{array}$ & $\begin{array}{l}0 \cdot 11 \\
0 \cdot 10\end{array}$ & $\begin{array}{l}0.09 \\
0.14\end{array}$ & $\begin{array}{l}0.10 \\
0.07\end{array}$ & $\begin{array}{l}0.09 \\
0.10\end{array}$ \\
\hline $330-369$ & & $\frac{1}{2}$ & 二 & $\begin{array}{c}0.01 \\
-\end{array}$ & $\begin{array}{l}0.01 \\
0.02\end{array}$ & $\begin{array}{l}0.01 \\
0.01\end{array}$ & $\begin{array}{l}0.09 \\
0.05\end{array}$ & & 二 & 二 & $\begin{array}{l}0.02 \\
0.02\end{array}$ & $\begin{array}{l}0.02 \\
0.01\end{array}$ & $\begin{array}{l}0.05 \\
0.03\end{array}$ & $\begin{array}{l}0.02 \\
0.02\end{array}$ \\
\hline $370-389$ & Diseases of eye & $\begin{array}{l}1 \\
2\end{array}$ & $\begin{array}{l}0.05 \\
0.15\end{array}$ & $\begin{array}{l}0.05 \\
0.06\end{array}$ & $\begin{array}{l}0.05 \\
0.06\end{array}$ & $\begin{array}{l}0.04 \\
0.01\end{array}$ & $\begin{array}{l}0.03 \\
0.03\end{array}$ & $\begin{array}{l}0.04 \\
0.05\end{array}$ & $\begin{array}{l}0.09 \\
0.07\end{array}$ & $\begin{array}{l}0.08 \\
0.10\end{array}$ & $\begin{array}{l}0.09 \\
0.04\end{array}$ & $\begin{array}{l}0.05 \\
0.05\end{array}$ & $\begin{array}{l}0.06 \\
0.11\end{array}$ & $\begin{array}{l}0.07 \\
0.07\end{array}$ \\
\hline $390-398$ & Diseas & $\begin{array}{l}1 \\
2 \\
\end{array}$ & $\begin{array}{l}0 \cdot 14 \\
0 \cdot 30 \\
\end{array}$ & $\begin{array}{l}0.12 \\
0.15 \\
\end{array}$ & $\begin{array}{l}0.06 \\
0.09 \\
\end{array}$ & $\begin{array}{l}0.08 \\
0.05 \\
\end{array}$ & $\begin{array}{l}0 \cdot 11 \\
0 \cdot 14 \\
\end{array}$ & $\begin{array}{l}0 \cdot 09 \\
0 \cdot 12 \\
\end{array}$ & $\begin{array}{l}0 \cdot 23 \\
0 \cdot 10\end{array}$ & $\begin{array}{l}0.09 \\
0 \cdot 15 \\
\end{array}$ & $\begin{array}{l}0.06 \\
0.07\end{array}$ & $\begin{array}{l}0.07 \\
0.09\end{array}$ & $\begin{array}{l}0.05 \\
0.07 \\
\end{array}$ & $\begin{array}{l}0.07 \\
0.09\end{array}$ \\
\hline $400-468$ & Card & $\begin{array}{l}1 \\
2\end{array}$ & $\begin{array}{c}0.05 \\
-\end{array}$ & $\stackrel{0.01}{-}$ & $\begin{array}{l}0.02 \\
0.02\end{array}$ & $\begin{array}{l}0.07 \\
0.07\end{array}$ & $\begin{array}{l}0 \cdot 18 \\
0 \cdot 23\end{array}$ & $\begin{array}{l}0.07 \\
0.07\end{array}$ & 二 & $\stackrel{0.01}{-}$ & $\begin{array}{l}0.06 \\
0.06\end{array}$ & $\begin{array}{l}0.09 \\
0.08\end{array}$ & $\begin{array}{l}0 \cdot 26 \\
0 \cdot 21\end{array}$ & $\begin{array}{l}0 \cdot 11 \\
0 \cdot 09\end{array}$ \\
\hline $470-527$ & $\begin{array}{l}\text { Diseases of respiratory } \\
\text { tract, with influenza }\end{array}$ & $\frac{1}{2}$ & $\begin{array}{l}0 \cdot 88 \\
0 \cdot 80 \\
\end{array}$ & $\begin{array}{l}0.55 \\
1.00 \\
\end{array}$ & $\begin{array}{l}0 \cdot 20 \\
0.31\end{array}$ & $\begin{array}{l}0 \cdot 18 \\
0 \cdot 20\end{array}$ & $\begin{array}{l}0 \cdot 30 \\
0 \cdot 27\end{array}$ & $\begin{array}{l}0.32 \\
0.43 \\
\end{array}$ & $\begin{array}{l}0.66 \\
0.83\end{array}$ & $\begin{array}{l}0.57 \\
0.70\end{array}$ & $\begin{array}{l}0 \cdot 22 \\
0.33\end{array}$ & $\begin{array}{l}0 \cdot 22 \\
0.25 \\
\end{array}$ & $\begin{array}{l}0 \cdot 13 \\
0 \cdot 22 \\
\end{array}$ & $\begin{array}{l}0 \cdot 26 \\
0.34 \\
\end{array}$ \\
\hline $530-587$ & & $\frac{1}{2}$ & $\begin{array}{l}0 \cdot 26 \\
0 \cdot 20 \\
\end{array}$ & $\begin{array}{l}0 \cdot 22 \\
0 \cdot 14 \\
\end{array}$ & $\begin{array}{l}0 \cdot 08 \\
0 \cdot 10 \\
\end{array}$ & $\begin{array}{l}0.08 \\
0.06 \\
\end{array}$ & $\begin{array}{l}0 \cdot 14 \\
0 \cdot 14 \\
\end{array}$ & $\begin{array}{l}0 \cdot 13 \\
0 \cdot 11 \\
\end{array}$ & $\begin{array}{l}0 \cdot 20 \\
0 \cdot 17 \\
\end{array}$ & $\begin{array}{l}0.07 \\
0 \cdot 10 \\
\end{array}$ & $\begin{array}{l}0.07 \\
0.11 \\
\end{array}$ & $\begin{array}{l}0.09 \\
0.07 \\
\end{array}$ & $\begin{array}{l}0 \cdot 18 \\
0 \cdot 09 \\
\end{array}$ & $\begin{array}{l}0.11 \\
0.09\end{array}$ \\
\hline $590-617$ & $\begin{array}{l}\text { Urinary infections and dis- } \\
\text { eases of male genital organs }\end{array}$ & 1 & $\begin{array}{l}0.12 \\
0.08 \\
\end{array}$ & $\begin{array}{l}0.01 \\
0.01\end{array}$ & $\begin{array}{l}0.02 \\
0.01\end{array}$ & $\begin{array}{l}0.02 \\
0.01 \\
\end{array}$ & $\begin{array}{l}0.08 \\
0.06\end{array}$ & $\begin{array}{l}0.04 \\
0.02\end{array}$ & $\overline{0.03}$ & $\stackrel{0.05}{-}$ & $\begin{array}{l}0.02 \\
0.004\end{array}$ & $\begin{array}{l}0.02 \\
0.03\end{array}$ & $\begin{array}{l}0.04 \\
0.04\end{array}$ & $\begin{array}{l}0.02 \\
0.02\end{array}$ \\
\hline $620-689$ & $\begin{array}{l}\text { Diseases of female genital } \\
\text { organs, with deliveries }\end{array}$ & $\frac{1}{2}$ & 二 & 二 & 二 & - & 二 & 二 & 二 & $\overline{0.01}$ & $\begin{array}{l}0 \cdot 15 \\
0 \cdot 15\end{array}$ & $\begin{array}{l}0.13 \\
0.08\end{array}$ & $\begin{array}{l}0.04 \\
0.04\end{array}$ & $\begin{array}{l}0.09 \\
0.08\end{array}$ \\
\hline $690-716$ & $\begin{array}{l}\text { Skin diseases } \\
\text { infections }\end{array}$ & $\frac{1}{2}$ & $\begin{array}{l}0 \cdot 07 \\
0 \cdot 10\end{array}$ & $\begin{array}{l}0 \cdot 13 \\
0 \cdot 20\end{array}$ & $\begin{array}{l}0 \cdot 14 \\
0 \cdot 24\end{array}$ & $\begin{array}{l}0 \cdot 11 \\
0 \cdot 10\end{array}$ & $\begin{array}{l}0 \cdot 13 \\
0 \cdot 10\end{array}$ & $\begin{array}{l}0 \cdot 12 \\
0.16 \\
\end{array}$ & $\overline{0.07}$ & $\begin{array}{l}0 \cdot 14 \\
0 \cdot 22 \\
\end{array}$ & $\begin{array}{l}0 \cdot 16 \\
0 \cdot 19\end{array}$ & $\begin{array}{l}0.15 \\
0 \cdot 14 \\
\end{array}$ & $\begin{array}{l}0 \cdot 13 \\
0 \cdot 12\end{array}$ & $\begin{array}{l}0 \cdot 14 \\
0 \cdot 16 \\
\end{array}$ \\
\hline $720-749$ & $\begin{array}{l}\text { Chronic rheumatism ar } \\
\text { ditions of organs of mo }\end{array}$ & $\frac{1}{2}$ & $0 \overline{0}$ & 0.01 & $\begin{array}{l}0.03 \\
0.01 \\
\end{array}$ & $\begin{array}{l}0 \cdot 15 \\
0 \cdot 11 \\
\end{array}$ & $\begin{array}{l}0 \cdot 14 \\
0 \cdot 14 \\
\end{array}$ & $\begin{array}{l}0.08 \\
0.07 \\
\end{array}$ & 二 & $0 \overline{0.03}$ & $\begin{array}{l}0.05 \\
0.09 \\
\end{array}$ & $\begin{array}{l}0 \cdot 15 \\
0 \cdot 17 \\
\end{array}$ & $\begin{array}{l}0.17 \\
0.12 \\
\end{array}$ & $\begin{array}{l}0 \cdot 10 \\
0 \cdot 12 \\
\end{array}$ \\
\hline $750-795$ & $\begin{array}{l}\text { Other and ill-defined } \\
\text { conditions }\end{array}$ & $\frac{1}{2}$ & $\begin{array}{l}0.12 \\
0.05\end{array}$ & $\begin{array}{l}0 \cdot 10 \\
0 \cdot 02\end{array}$ & $\begin{array}{l}0.05 \\
0.04 \\
\end{array}$ & $\begin{array}{l}0 \cdot 04 \\
0 \cdot 04\end{array}$ & $\begin{array}{l}0.05 \\
0.04\end{array}$ & $\begin{array}{l}0.06 \\
0.04\end{array}$ & $\begin{array}{l}0 \cdot 09 \\
0 \cdot 14\end{array}$ & $\begin{array}{l}0.09 \\
0.09\end{array}$ & $\begin{array}{l}0.04 \\
0.06\end{array}$ & $\begin{array}{l}0.06 \\
0.04\end{array}$ & $\begin{array}{l}0.08 \\
0.08\end{array}$ & $\begin{array}{l}0.06 \\
0.07\end{array}$ \\
\hline N800-995 & Injuries & $\begin{array}{l}1 \\
2 \\
\end{array}$ & $\begin{array}{l}0 \cdot 16 \\
0 \cdot 23 \\
\end{array}$ & $\begin{array}{l}0 \cdot 20 \\
0 \cdot 19 \\
\end{array}$ & $\begin{array}{l}0 \cdot 15 \\
0 \cdot 17 \\
\end{array}$ & $\begin{array}{l}0.05 \\
0 \cdot 13 \\
\end{array}$ & $\begin{array}{l}0.09 \\
0.03\end{array}$ & $\begin{array}{l}0 \cdot 12 \\
0 \cdot 14 \\
\end{array}$ & $\begin{array}{l}0.26 \\
0.03 \\
\end{array}$ & $\begin{array}{l}0 \cdot 17 \\
0 \cdot 16 \\
\end{array}$ & $\begin{array}{l}0.09 \\
0.08 \\
\end{array}$ & $\begin{array}{l}0 \cdot 11 \\
0 \cdot 12 \\
\end{array}$ & $\begin{array}{l}0 \cdot 12 \\
0 \cdot 12 \\
\end{array}$ & $\begin{array}{l}0 \cdot 12 \\
0 \cdot 11 \\
\end{array}$ \\
\hline $\begin{array}{l}\text { N997-999 } \\
\text { Y00-09 }\end{array}$ & $\begin{array}{l}\text { Immunization, vaccination, } \\
\text { reaction to drugs, etc. }\end{array}$ & $\frac{1}{2}$ & $\begin{array}{l}0.21 \\
0.25\end{array}$ & $\begin{array}{l}0.10 \\
0.09\end{array}$ & $\begin{array}{l}0.06 \\
0.03\end{array}$ & $\begin{array}{l}0.05 \\
0.03\end{array}$ & $\begin{array}{l}0.04 \\
0.05\end{array}$ & $\begin{array}{l}0.07 \\
0.06\end{array}$ & $\begin{array}{l}0.34 \\
0.31\end{array}$ & $\begin{array}{l}0.11 \\
0.01\end{array}$ & $\begin{array}{l}0.08 \\
0.04\end{array}$ & $\begin{array}{l}0.04 \\
0.02\end{array}$ & $\begin{array}{l}0.04 \\
0.03\end{array}$ & $\begin{array}{l}0.07 \\
0.04\end{array}$ \\
\hline Total & $\cdots$ & $\begin{array}{l}1 \\
2\end{array}$ & $\begin{array}{l}2.67 \\
2.93\end{array}$ & $\begin{array}{l}2 \cdot 15 \\
2 \cdot 46\end{array}$ & $\begin{array}{l}1 \cdot 06 \\
1 \cdot 21\end{array}$ & $\begin{array}{l}1.05 \\
0.99\end{array}$ & $\begin{array}{l}1.52 \\
1.38\end{array}$ & $\begin{array}{l}1.44 \\
1.52\end{array}$ & $\begin{array}{l}2 \cdot 54 \\
2 \cdot 31\end{array}$ & $\begin{array}{l}1 \cdot 84 \\
2 \cdot 09\end{array}$ & $\begin{array}{l}1.37 \\
1.46\end{array}$ & $\begin{array}{l}1.42 \\
1.41\end{array}$ & $\begin{array}{l}1.57 \\
1.43\end{array}$ & $\begin{array}{l}1.53 \\
1.54\end{array}$ \\
\hline
\end{tabular}

Amongst school children, respiratory diseases again caused the maximum average number of spells per patient. In the first year 0.55 was recorded for boys and 0.57 for girls and in the second year 1.00 and $0 \cdot 70$. These averages approximately represent about 25 to 40 per cent. of all spells in this age group. Infectious diseases accounted for the next highest average and account for about one-sixth of all spells of sickness among school children in the practice.
In the age group 15-39 years the averages were highest for respiratory disorders, 0.20 spells per male and 0.22 per female in the first year, and 0.31 and 0.33 in the second year. These conditions accounted for about 16 to 26 per cent. of all spells in the age group, injuries among men, mental and gynaecological conditions among women, and skin diseases among both sexes being the next most important. 
In the age group 40-59 years respiratory disorders were again highest with averages of 0.18 spells per male and 0.22 spells per female in the first year and 0.20 and 0.25 in the second year. These conditions accounted for between 15 and 20 per cent. of all spells in the age group, being followed by chronic rheumatism and conditions of the organs of movement, diseases of the female genital organs, skin diseases, and injuries.

Amongst the oldest patients in the practice, age group 60 and over, respiratory conditions again gave the highest average number of spells per patient among men $(0.30$ in the first year and 0.27 in the second), accounting for about 20 per cent. of all spells amongst men. Amongst women, the average for respiratory conditions was highest in the second year $(0 \cdot 22$, about 15 per cent. of the total), but it was abnormally low $(0 \cdot 13)$ in the first year. Cardiovascular diseases gave the highest female averages in the first year and about equalled respiratory disease in the second year, the averages being $0 \cdot 26$ and $0 \cdot 21$ spells per patient respectively. The cardiovascular group was second in importance amongst males, and in both sexes these two large groups were followed by chronic rheumatism and conditions of the organs of movement, skin diseases, and diseases of the alimentary tract with hernia.

Table VI indicates several age trends. Those which are consistently portrayed by each year of study are discussed below.

The infectious disease group gave the maximum average number of spells per patient before the age of 15 and thereafter fell with advancing age. Allergic disorders were most frequently encountered in the pre-school children and also diminished with advancing age. Diseases of the central nervous system were at a maximum in the highest age group. Cardiovascular diseases became more common as age advanced. Diseases of the female genital organs were at a maximum in the age group 15-39 years. Chronic rheumatism and conditions of the organs of movement became prominent from the age of $\mathbf{4 0}$ years onwards.

Some other age trends are suggested by a study of Table VI, but do not appear consistently. One is left with the impression that male patients were seen less frequently for respiratory conditions in the age groups 15-39 and 40-59 years than in other age groups, while female patients showed a steady downward trend with advancing age for these conditions. It is doubtful whether the data justify further speculation.

No consistent sex differences appear in Table VI and no consistent differences between the two years of study.
Although the large groups in Table VI have in fact been broken down and studied, the value of this analysis is lowered by the small numbers involved, and, except in the case of respiratory disease, these details of morbidity are therefore omitted.

A breakdown of the respiratory group reveals how large a proportion of infections of the respiratory tract were "bronchial" in character. This is clear when the number of spells of acute bronchitis and bronchial catarrh together are expressed as percentages of spells of respiratory illness. In males of all ages this proportion was 53 per cent. and in females 50 per cent. in the first year, 43 and 45 per cent. being observed in the second year. In the 0-4 year age group the percentages were 79 per cent. for boys and 74 per cent. for girls in the first year, compared with 63 and 33 per cent. in the second year. From 5 to 59 years the percentages varied between 31 and 53 per cent. In the age group 60 years and over the percentages were 53 for men and 67 for women in the first year, and 67 and 75 in the second year.

Acute colds comprised only 11 per cent. of all respiratory conditions during the first year, 9 per cent. in the second. More variation occurred for tonsillitis and influenza. The former during the first year comprised only 8 per cent. of respiratory illness, the latter 3 per cent. During the second year the corresponding figures were 17 and 16 per cent. The figures for influenza are, however, still small, and there was no real epidemic during the second year.

It is often said that psycho-neuroses and psychosomatic disorders generally account for a large part of general practice. An attempt has been made, based on spells of medical attention, to estimate their frequency in this material.

The basis for this grouping of psycho-somatic disorders is wide and includes all cases of allergic and hyperthyroid disease, peptic ulcer and indigestion of uncertain origin, skin conditions with a possible psycho-somatic basis, most of the ill-defined group, and all the psycho-neuroses.

Such spells amount to 345 (16.7 per cent.) of the total spells in the first year and 320 (15.6 per cent.) in the second year.

Although the numbers involved are small, the data suggest that after the age of 15 women experienced relatively more spells of such disorders than men in both years, but no evidence of any other association with age was apparent, except that there is a suggestion of rather high incidence among boys which is mainly attributable to allergic disorders. 
TABLE VII

PATIENTS REFERRED TO HOSPITAL EXTERN DEPARTMENTS AND SPECIALISTS DURING THE YEARS 1951-52 AND 1952-53

\begin{tabular}{|c|c|c|c|c|c|c|c|c|c|}
\hline \multirow{2}{*}{\multicolumn{2}{|c|}{ Patients Referred to }} & \multirow[b]{2}{*}{ Year } & \multicolumn{6}{|c|}{ Specialty } & \multirow[b]{2}{*}{ Total } \\
\hline & & & Medical & $\begin{array}{l}\text { Surgical and } \\
\text { Gynaecological }\end{array}$ & $\begin{array}{c}\text { Rheumatic } \\
\text { and } \\
\text { Orthopaedic }\end{array}$ & $\begin{array}{c}\text { Ophthalmo- } \\
\text { logical }\end{array}$ & $\begin{array}{l}\text { Ear, Nose } \\
\text { and Throat }\end{array}$ & Skin & \\
\hline \multirow{4}{*}{ Male } & \multirow{2}{*}{$\begin{array}{l}\text { Hospital } \\
\text { Extern } \\
\text { Department }\end{array}$} & 1 & 17 & 14 & 18 & 4 & 8 & 5 & 66 \\
\hline & & 2 & 15 & 8 & 13 & 2 & 7 & 6 & 51 \\
\hline & \multirow{2}{*}{ Specialist } & 1 & 12 & 9 & 12 & 2 & 6 & -4 & 45 \\
\hline & & 2 & 18 & 6 & 2 & 2 & 11 & 4 & 43 \\
\hline \multirow{4}{*}{ Female } & \multirow{2}{*}{$\begin{array}{l}\text { Hospital } \\
\text { Extern } \\
\text { Department }\end{array}$} & 1 & 28 & 13 & 31 & 2 & 5 & 4 & 83 \\
\hline & & 2 & 17 & 14 & 22 & 2 & 2 & 7 & 64 \\
\hline & \multirow{2}{*}{ Specialist } & 1 & 19 & 12 & 11 & 13 & 8 & 6 & 69 \\
\hline & & 2 & 24 & 18 & 12 & 11 & 9 & 10 & 84 \\
\hline
\end{tabular}

\section{Use of Hospital SeRvices and Consultants}

Tables VII and VIII give an indication of the use made of hospital and specialist services by the patients in this practice. It should be noted that in these Tables an individual patient may appear more than once.

Table VII shows the numbers of patients referred to hospital extern departments and to specialists during the 2 years of study. In different practices the relative numbers naturally vary, but the frequency with which patients elect to go to specialists in this practice may cause surprise. Except in the case of females during the second year, however, hospital externs were rather more frequently attended. During the 2 years there were in all 205 referrals of males and 300 of females. Only fifteen children under 5 years were referred to externs and specialists, seven of these to the ear, nose, and throat department, a speciality which involved about 40 per cent. of the 56 children in the 5 to 15 year group over the 2 years. Many of the patients referred as rheumatic and orthopaedic cases were assigned to the physiotherapy department.

Consultations with specialists usually took place at the specialist's consulting room, but 47 were domiciliary visits undertaken over the 2 years under an arrangement of the Northern Ireland Hospitals Authority. Many patients were prepared to spend a few guineas to see a consultant privately, to avoid the disadvantages of the hospital out-patient department, even with an appointment system there is sometimes considerable delay. The consultation figures, in private and at hospital, include no cases sent only for refraction.

Table VIII shows admissions to hospitals and pay clinics (including nursing homes). In males only, a preponderant use of hospitals as opposed to pay clinics in the first year was completely reversed in the second. This is not easy to explain, but the frequency with which pay clinics were used was undoubtedly due in part to the increasing popularity of associations which insure against the expenses of pay clinics and specialist attention. No cases of eye or skin disease were admitted during either year.

\section{MORTALITY}

The deaths in the practice during the 2 years have not yet been mentioned. As these patients were

TABLE VIII

ADMISSIONS TO HOSPITALS OR PAY CLINICS DURING THE YEARS 1951-52 AND 1952-53

\begin{tabular}{|c|c|c|c|c|c|c|c|c|c|c|c|c|}
\hline & & & \multicolumn{8}{|c|}{ Specialty } & \multirow{2}{*}{\multicolumn{2}{|c|}{ Total }} \\
\hline \multirow{2}{*}{\multicolumn{3}{|c|}{ Patients Admitted to }} & \multicolumn{2}{|c|}{ Medical } & \multicolumn{2}{|c|}{$\begin{array}{l}\text { Surgical and } \\
\text { Gynaecological }\end{array}$} & \multicolumn{2}{|c|}{$\begin{array}{c}\text { Rheumatic and } \\
\text { Orthopaedic }\end{array}$} & \multicolumn{2}{|c|}{$\begin{array}{l}\text { Ear, Nose, } \\
\text { and Throat }\end{array}$} & & \\
\hline & & & Year 1 & Year 2 & Year 1 & Year 2 & Year 1 & Year 2 & Year 1 & Year 2 & Year 1 & Year 2 \\
\hline \multirow[t]{2}{*}{ Male } & $\begin{array}{l}\text { Hospital .. } \\
\text { Pay Clinic }\end{array}$ & $\ddot{*}$ & $\begin{array}{l}6 \\
1 \\
\end{array}$ & $\begin{array}{l}2 \\
8\end{array}$ & $\begin{array}{l}8 \\
3\end{array}$ & $\begin{array}{l}2 \\
8\end{array}$ & 1 & 1 & $\begin{array}{l}3 \\
2\end{array}$ & $\begin{array}{l}1 \\
6\end{array}$ & $\begin{array}{r}18 \\
6\end{array}$ & $\begin{array}{r}6 \\
22\end{array}$ \\
\hline & Total $\quad \cdots$ & $\cdots$ & 7 & 10 & 11 & 10 & 1 & 1 & 5 & 7 & 24 & 28 \\
\hline \multirow[t]{2}{*}{ Female } & $\begin{array}{l}\text { Hospital ... } \\
\text { Pay Clinic }\end{array}$ & $\ddot{*}$ & $\begin{array}{l}4 \\
4 \\
\end{array}$ & $\begin{array}{l}4 \\
5 \\
\end{array}$ & $\begin{array}{l}5 \\
7 \\
\end{array}$ & $\begin{array}{l}9 \\
9 \\
\end{array}$ & $\begin{array}{l}6 \\
4 \\
\end{array}$ & $\begin{array}{l}3 \\
1 \\
\end{array}$ & $\begin{array}{l}1 \\
3\end{array}$ & $\overline{2}$ & $\begin{array}{l}16 \\
18 \\
\end{array}$ & $\begin{array}{l}16 \\
17 \\
\end{array}$ \\
\hline & Total & $\cdots$ & 8 & 9 & 12 & 18 & 10 & 4 & 4 & 2 & 34 & 33 \\
\hline
\end{tabular}


among those who were not on the register for a full year they were excluded from the main survey.

In the first year there were fifteen deaths, nine of females and six of males, the average age at death being 73 years. The great majority resulted from the effects of old age and arterial degeneration in some form. In these old people the exact pathological factors contributing to death were often difficult to determine and in eight cases the term "cardiac failure" was used; in four of these senile dementia was also present. Two other deaths were due to coronary thrombosis and two more to cerebral haemorrhage and thrombosis. There were two cases of malignant disease and one of embolism following prostatectomy.

In the second year there were ten deaths, four of females and six of males. Cardiovascular disease in old age accounted for five patients, two of which were suffering from senile dementia and one from coronary thrombosis. Malignant disease was responsible for three deaths and one resulted from uraemia with prostatic enlargement. The remaining death was that of a baby 10 days old, caused by a rare virus carditis. Excluding this infant death the average age was again 73 years.

\section{BIRTHS}

Births have also been excluded from what has gone before. Six male and six female babies were born to mothers who were on the register during the whole of the first year, and six male and three female during the second year.

Midwifery has never been heavy in the practicepossibly twenty cases a year occurred before 1948and the volume of work is rapidly decreasing because of a decision to discourage midwifery and not to undertake such work under the terms of the Health Service. During the first year ten maternity patients were referred to hospital, six elected to go to specialists, and five were delivered by me. During the second no patients were delivered personally; six were referred to hospital, and five chose to attend specialists.

\section{COMPARISON OF WORK DONE WITH WORK DESCRIBED IN OTHER SURVEYS}

Previous accounts include those of McGregor (1953), 2,562 patients in a rural practice centring on a small town; Fry (1952), a lower middle-class urban practice with a population of 4,456 studied in less detail; Backett and others (1953, 1954), a very full investigation of a working-class practice of 3,084 persons.

There is also the analysis of eight varying practices by Logan (1953) which is a mine of information. It is clear from these studies and my own that the age and sex composition of the patients in the practice plays an important part in the volume and type of work needed. Any comparison between practices must therefore take these factors into account, unless the patients are fortuitously similarly distributed in age and sex groups. It is equally important, if practices are to be compared, that the members should as far as possible be of the same social class.

The age groups in other investigations are not always those of the present survey, but various comparisons may be made. The sex ratio of the present practice averaged 42.05 males per 100 patients for the two years. Fry's figure was $48 \cdot 25$ males per 100 patients, McGregor's $47 \cdot 07$, and that of the General Register Office investigation $44 \cdot 3$. McGregor's figures, and those in Table I show more males than females under the age of 15 . The General Register Office figures here are almost identical for the two sexes. The high percentage of the practice ( 21.8 per cent.) aged 60 years and over is much in excess of the figures for other surveys, Fry's figure, for example, being 13 per cent.

The second year of the present survey was exceptional in that the males required slightly more attention from "all causes" than the females. During the first year of this study, and in the practices of McGregor, Fry, and Backett and others, and all the eight practices of the General Register Office investigation, females always received relatively more attention.

The average number of surgery attendances and home visits combined per patient for the 2 years of the present survey is $3 \cdot 19$, which approximates to the figure given by Fry $(3 \cdot 28)$ and that in the General Register Office's analysis $(3 \cdot 78)$. On the other hand McGregor's figure is 5.9, and that of Backett and others is $5 \cdot 1$. All the investigations agree that more frequent attention is given to the very young and to the very old.

The ratio of home visits to surgery attendances in the studies of McGregor, Backett and others, and the General Register Office follows in each case the age pattern to be observed in the present data. McGregor also tabulates frequency distributions of the number of illnesses of his patients, which are essentially identical with the spells of medical attention defined in this paper. Only McGregor gives comparable figures of this nature. The percentages of those who required no medical attention during the year may also be contrasted; those for the present survey, and for McGregor, Fry, and Backett and others are $34 \cdot 8,31 \cdot 4,25$, and 28 per cent. respectively. 


\section{SUMMARY}

(1) The work done in a Belfast suburban practice during two consecutive years (November to October, 1951-2, and 1952-3) is described.

(2) The statistics, apart from births and deaths, are based on 1,384 patients on the register throughout the first year and 1,341 in the second year, classified by sex and age group (0-4, 5-14, 15-39, 40-59, and 60 and over).

(3) Over the 2-year period there were $3 \cdot 19$ home visits and/or surgery attendances per patient on the register. This index was highest at the extremes of the age range, and at those ages greater among males than females.

(4) Up to age 15 and over age 60 years, home visits were relatively more common than surgery attendances, so that the very young and old required not only more attention but also a different type of attention.

(5) Between 30 and 36 per cent. of the patients on the register were not seen professionally during a year. Up to age 60 this proportion increased with advancing age.

(6) There were approximately 1.5 spells of medical attention per patient in each year, and this average was least among young and middle-aged adults.

(7) The average number of home visits and/or surgery attendances per spell of medical attention varied from about 1.5 in children to about 3 in the oldest age group.

(8) The morbidity data of Table VI focus attention on respiratory disorders. As the predominant cause of sickness in each age group and at all ages they accounted for nearly a quarter of the total number of spells of medical attention.

(9) No consistent differences in the morbidity experience were apparent between the 2 years of study or between the sexes.

(10) Although the numbers involved are small, tentative remarks have been made about the age distribution of some conditions, the "psychoneuroses", and the use made of hospital and consultant services.

(11) Comparison is made with other reported work.

My chief indebtedness is to Dr. E. A. Cheeseman, Reader in Medical Statistics in the Department of Social and Preventive Medicine, The Queen's University of Belfast, for his constant and unfailing help and advice.

Mr. J. D. Merrett and the late Miss Margaret Moran of the Department of Social and Preventive Medicine did much careful and exacting work in the preparation of the figures.

I am most grateful to Dr. J. H. Adams for his help in maintaining the continuity of the records in my absence.

\section{REFERENCES}

Backett, E. M., Shaw, L. A., and Evans, J. C. G. (1953). Proc. roy Soc. Med., 46, 707.

$\longrightarrow$, Heady, J. A., and Evans, J. C. G. (1954). Brit. med. J., 1, 109

Fry, J. (1952). Ibid., 2, 249.

Logan, W. P. D. (1953). "General Practitioners' Records". Studies? on Medical and Population Subjects, No. 7. General Register Office, H.M.S.O., London.

McGregor, R. M. (1949). Hlth Bull. (Edinb.), 7, 48.

—_ (1950). Edinb. med. J., 57, 433.

- (1953). Hlth Bull. (Edinb.), 11, 14.

World Health Organization (1948). "Manual of the International Statistical Classification of Diseases, Injuries, and Causes of Death". W.H.O., Geneva; H.M.S.O., London. 